\title{
The Asymmetric Effect of Inflation on Economic Growth in Vietnam: Evidence by Nonlinear ARDL Approach
}

\author{
Bui Hoang NGOC* \\ Received: November 24, 2019 Revised: December 11, 2019 Accepted: December 18, 2019
}

\begin{abstract}
Low inflation and sustainable growth have been the major macroeconomic goals being pursued by every developing country, Vietnam inclusive. The effect of inflation on economic growth has been intensively analyzed by a variety of studies, but the empirical evidence more often than not remains controversial and ambiguous. One common hypothesis of previous studies is that they have assumed that the effect of inflation on growth is symmetric. The main purpose of this study is to investigate the asymmetric effect of inflation and money supply on economic growth using the Nonlinear Autoregressive Distributed Lag approach introduced by Shin, Byungchul, and Greenwood-nimmo (2013) for Vietnam over the period 1990-2017. Empirical results provide evidence that the effects of inflation on economic growth are negative and asymmetric in the long run. The impact of money supply on growth is positive in both the short-run and long-run. Accordingly, the impact of the increase in the inflation rate is bigger than the decreasing in the long-run. This different impact is significant and high inflation will destruct economic activities. As a result, the study provides empirical evidence for the authorities to plan monetary policies and control the rate of inflation to achieve sustainable economic development in the long-run.
\end{abstract}

Keywords: Inflation, Money supply, Economic Growth, Asymmetry, Vietnam.

JEL Classification Code: E31, E44, E51, E52, O42.

\section{Introduction}

In economic literature, the inflation rate is equal to the growth rate of nominal money minus the rate of economic growth. A crucial objective of monetary policy is to achieve high and sustainable rates of economic growth along with low and stable rates of inflation (Wulandari, Utomo, Narmaditya, \& Kamaludin, 2019). Therefore, the question relating to the effects of inflation on economic growth is an intensely interesting subject of policy_maker and academic. Although this subject is still debated, empirical studies are generally accepted that inflation has a negative impact on the medium and long-run growth (Bruno \& Easterly, 1998; Fischer, 1993). This conclusion implies that monetary authority should maintain a low level of inflation. But, Tobin (1965) finds that inflation has a positive effect on

\footnotetext{
${ }^{*}$ First Author and Corresponding author. Ph.D. Candidate, Graduate School, Ho Chi Minh City Open University, Vietnam [Postal address: 97 Vo Van Tan Street, Ward 6, District 3, Ho Chi Minh City 700000, Vietnam.] Email: ngocbh.16ae@ou.edu.vn (c) Copyright: Korean Distribution Science Association (KODISA)

This is an Open Access article distributed under the terms of the Creative Commons Attribution NonCommercial License (https://creativecommons.org/licenses/by-nc/4.0/) which permits unrestricted noncommercial use, distribution, and reproduction in any medium, provided the original work is properly cited.
}

growth. There are no effects of inflation on economic growth is a conclusion of Sidrauski (1967).

Over the last few decades, the inflation targeting regime is the crucial objective of the central banks in several countries. So, an important question is what should be the inflation target and how it is a suitable framework for the inflation target regime. According to Khan and Senhadji (2000), the levels of annual inflation between $1 \%$ and $3 \%$ is a suitable rate for industrialized countries, and between 11 and $12 \%$ for developing countries. The empirical results of Khan and Senhadji show that inflation significantly reduces growth above this threshold. At the high threshold, inflation can be destructed economic activities which reduce the variations in relative prices and, thus the negative effects of inflation on growth (Ibarra \& Trupkin, 2016). Although the non-linearity of the inflation-growth nexus seems to be widely accepted, there are still controversies about: First, the level of inflation that acts as the threshold (Hung, 2017; Lam, 2015); Second, the sensitivity of this non-linear relationship to the frequency of the data, the considered framework (cross-country/time series) and the methodology used, the countries under study (developed/developing), and the existence of high inflation observation (Gillman \& Harris, 2010; Lopez-Villavicencio \& Mignon, 2011). 
The rate of inflation is mainly depended on the amount of money supply by central banks. One common hypothesis of previous studies is that they have assumed that the effect of inflation on growth is symmetric. That means, at the low of inflation rate, an increase in the rate of inflation increases economic growth whereas a decrease in the rate of inflation decreases economic growth with the same magnitude. At the high of inflation rate, a decrease in the rate of inflation increases economic growth whereas an increase in the rate of inflation decreases economic growth with the same magnitude. There are several reasons to believe that such assumptions are not really reasonable, because: (i) Capital or labor are two main factors contributing to economic growth. In the period of economic growth, the contribution ratio of these factors must differ from the economic recession; (ii) The effects of inflation on economic growth depends on how the money is pumped into the economy and the money demand elasticity. Asymmetry effects are the different impact of the stage increases the money supply and the stage reduction of the money supply to economic growth. This asymmetric effect is the main goal in which the article wants to investigate the relationship between inflation, money supply and economic growth for Vietnam.
The remainder of the paper is as follows: Section 2 presents the theoretical background and reviews the relevant literature, section 3 shows research model, data sources and methodology, section 4 presents results interpretations and section 5 concludes and suggest several policy implications.

\section{Theoretical Background and Literature Review}

In the 1960s with the high-growth and low-inflation, the traditional view that inflation was destructive no longer seemed so compelling. It was the golden age of the Phillips Curve, in which economic growth and inflation were positively related in the short run. Even in the long run, Tobin (1965) find a positive effect on growth from higher inflation. There are no effects of inflation on growth is a conclusion of the study by Sidrauski (1967). According to them, when inflation was high, wealth would be reallocated away from money and onto physical capital. This conclusion is supported by the study of Wallich (1969).

Table 1: Summary of existing empirical studies

\begin{tabular}{|c|c|c|l|}
\hline Authors & Countries & Methodology & Conclusions \\
\hline Hayat et al. (2018) & Pakistan & Threshold technique & The low inflation would be help achieve sustainable real economic growth \\
\hline Ayres et al. (2014) & Six regions & OLS, FE & The impact of inflation targeting on real GDP is minimal overall \\
\hline Law \& Singh (2014) & 87 countries & $\begin{array}{c}\text { Dynamic panel threshold } \\
\text { technique }\end{array}$ & $\begin{array}{l}\text { The level of financial development is beneficial to growth only up to a } \\
\text { certain threshold; beyond the threshold level further development of finance } \\
\text { tends to affect growth adversely }\end{array}$ \\
\hline Bhar \& Mallik (2010) & United State & $\begin{array}{c}\text { Multivariate EGARCH- } \\
\text { M model }\end{array}$ & $\begin{array}{l}\text { Inflation uncertainty has a positive and significant effect on the level of } \\
\text { inflation and a negative and significant effect on output growth. }\end{array}$ \\
\hline Kiat (2008) & $\begin{array}{c}30 \text { countries in } \\
\text { South Africa }\end{array}$ & $\begin{array}{c}\text { Ordinary Least Square } \\
\text { (1998) }\end{array}$ & Inflation has a negative impact on growth \\
\hline $\begin{array}{c}\text { Bruno \& Easterly } \\
\text { Fountas (2010) }\end{array}$ & 21 countries & Threshold technique & Growth falls sharply during discrete high inflation crises (40\%). \\
\hline $\begin{array}{c}\text { Vaona \& Schiavo } \\
(2007)\end{array}$ & 167 countries & $\begin{array}{c}\text { Nonparametric and } \\
\text { semiparametric } \\
\text { estimator }\end{array}$ & $\begin{array}{l}\text { Inflation uncertainty is not detrimental to output growth } \\
\text { it their relationship becomes markedly negative and steeper. }\end{array}$ \\
\hline $\begin{array}{c}\text { Rousseau \& } \\
\text { Yilmazkuday (2009) }\end{array}$ & 84 countries & $\begin{array}{c}\text { Trilateral graphical } \\
\text { approach }\end{array}$ & Growth is generally much lower in such high-inflation. \\
\hline Ilyas et al. (2014) & Pakistan & 2SLS technique & Inflation negatively and significantly affects economic growth. \\
\hline $\begin{array}{c}\text { Munir et al. (2009) } \\
\text { Malaysia }\end{array}$ & $\begin{array}{c}\text { Threshold autoregressive } \\
\text { significantly retards the growth rate of GDP. Below the threshold level, there } \\
\text { is a statistically significant positive relationship between inflation rate and } \\
\text { growth. }\end{array}$ \\
\hline
\end{tabular}

The economic literature pointed out that high inflation was inherently unstable. In the last two decades, central banks in several countries have adopted an inflationtargeting regime. In order to examine the inflation-growth nexus, various several studies were applied to the nonlinear models. The pioneering study of Fischer (1993) is one of the first studies examining the relationship between inflation and growth by threshold technique. Using panel data for a set of developed and developing countries, Fischer finds a non-linear negative impact on growth from inflation. Following, Khan and Senhadji (2000) find strong evidence statistic to show that inflation significantly reduces growth. In non-industrialized countries, high inflation can be destructed indexation systems which increase relative prices and marginal costs. The increasing relative prices may be harm growth in the long run. 
The existence of such a non-linear pattern has been confirmed by other authors, such as Burdekin, Denzau, Keil, Sitthiyot, and Willett (2004); Ghosh and Phillips (1998); Gillman and Harris (2010). From a theoretical background, the effects of inflation on growth are also mixed and depend on the way money is introduced in the models. According to Dornbusch and Frenkel (1973), if money is introduced through a pecuniary transaction cost function, the real effect of money is ambiguous. When money serves as a transaction device through the shopping, the predictions of the effects of money on growth become more clear. In endogenous growth models, the relationship between inflation and growth is accounted for via the marginal product of capital, being either physical capital (AK models) or human capital (AH models), or both. In AK models, money plays as physical capital, thus the inflation rate impacts the growth rate through its effects on the rate return of capital (Gillman \& Harris, 2010; Lopez-Villavicencio \& Mignon, 2011). Accordingly, inflation acts as a tax on physical capital that decreases the rate of return to capital and tends to lower economic growth. In $\mathrm{AH}$ models, inflation plays as a tax on human capital and also impacts the output growth rate. It leads to substitution between goods and leisure, decreasing the return to human capital, thus reduces the economic growth rate.

In sum, the effects of inflation and money supply on growth were still surprisingly ambiguous. Several empirical studies in table 1 provided evidence for this situation. As mentioned in the first section, one common hypothesis of previous studies is that they have assumed that the effects of inflation and money supply are symmetric. We suggest some reasons to believe that such assumptions are not reasonable. This gap reveals the necessity of further empirical research on the relationship between inflation and economic growth in Vietnam.

\section{Data and Research Methods}

\subsection{Model and Data Sources}

In order to investigate the asymmetric effect of inflation on the economic growth of Vietnam in the period 19902017 and following the previous research of (Fischer, 1993; Hwang, 2007; Tuan, 2013; Law \& Singh, 2014), we specify the research model, as follows:

$$
\begin{aligned}
& L n G D P_{t}=\lambda_{0}+\lambda_{1} \cdot I N F_{t}+\lambda_{2} \cdot M S_{t}+u_{t} \\
& \begin{array}{l}
\Delta L n G D P_{t}=\beta_{0}+\beta_{1} \cdot L n G D P_{t-1}+\beta_{2}^{+} \cdot I N F_{-} P O S_{t-1}+\beta_{2}^{-} \cdot I N F_{-} N E G_{t-1}+\beta_{3} \cdot M S_{t-1}+ \\
+\sum_{i=1}^{m 1} \alpha_{1 i} \cdot \Delta L n G D P_{t-i}+\sum_{i=0}^{m 2} \alpha_{2 i}^{+} \cdot \Delta I N F_{-} P O S_{t-i}+\sum_{i=0}^{m 3} \alpha_{2 i}^{-} \cdot \Delta I N F_{-} N E G_{t-i}+\sum_{i=0}^{m 4} \alpha_{3 i} \cdot \Delta M S_{t-i}+\mu_{t}
\end{array} \\
& \begin{array}{l}
\Delta L n G D P_{t}=\beta_{0}+\beta_{1} \cdot L n G D P_{t-1}+\beta_{2}^{+} \cdot I N F_{-} P O S_{t-1}+\beta_{2}^{-} \cdot I N F_{-} N E G_{t-1}+\beta_{3} \cdot M S_{t-1}+ \\
+\sum_{i=1}^{m 1} \alpha_{1 i} \cdot \Delta L n G D P_{t-i}+\sum_{i=0}^{m 2} \alpha_{2 i}^{+} \cdot \Delta I N F_{-} P O S_{t-i}+\sum_{i=0}^{m 3} \alpha_{2 i}^{-} \cdot \Delta I N F_{-} N E G_{t-i}+\sum_{i=0}^{m 4} \alpha_{3 i} \cdot \Delta M S_{t-i}+\mu_{t}
\end{array}
\end{aligned}
$$

The data is collected from 1990 to 2017 published by the World Bank. LnGDP is the logarithm of GDP per capita (at constant 2010 prices, unit: US dollar), INF is the rate of inflation (unit: percentage), and MS is the amount of broad money M2 per GDP (unit: percentage).

\subsection{Methodology}

Clearly, an estimate of Eq.1 only yields the long-run effects of exogenous variables. As mentioned in the literature review, the assumption of the symmetric impact of inflation maybe not exactly, because the increase or decrease in inflation may impact economic growth with varying degrees and orientation. In order to test the symmetry versus asymmetry effects of inflation, we follow Shin et al. (2013) and separate positive and negative changes in inflation as details:

$$
I N F_{t}=I N F_{0}+I N F_{-} P O S+I N F_{-} N E G
$$

where: $\mathrm{INF}_{0}$ is constant (it is natural inflation). Therefore, INF_POS and INF_NEG are the partial sums of positive and negative changes in inflation. These are calculated as follows:

$$
\begin{gathered}
I N F_{-} P O S=\sum_{i=1}^{t} \Delta I N F_{i}^{+}=\sum_{i=1}^{t} \max \left(\Delta I N F_{t}, 0\right) \\
I N F_{-} N E G=\sum_{i=1}^{t} \Delta I N F_{i}^{-}=\sum_{i=1}^{t} \min \left(\Delta I N F_{t}, 0\right) \\
\text { Note: } \Delta I N F_{t}=I N F_{t}-I N F_{t-1}
\end{gathered}
$$

The long-run relationship in Eq.1 can be rewritten as follows:

$L n G \mathrm{DP} P_{t}=\lambda_{0}+\lambda_{1}^{+} \cdot I N F_{-} P O S+\lambda_{1}^{-} \cdot I N F_{-} N E G+\lambda_{2} \cdot M S_{t}+\mu_{t}$

Note: $\lambda_{1}^{+}, \lambda_{1}^{-}, \lambda_{2}$ are regression coefficients that present long-run impacts

In order to infer the short-run effects, we follow Pesaran, Shin, and Smith (2001); Shin et al. (2013) Bounds testing approach and rewrite Eq. 2 as an Error Correction Model, as follows: 
where: $\Delta$ shows the first differences of the variables, $\beta_{\mathrm{i}}$ are coefficients of long-run impacts, $\alpha_{i}$ are coefficients of shortrun impacts, $\mu_{t}$ is the error.

$\mathrm{m}_{1}, \mathrm{~m}_{2}, \mathrm{~m}_{3}, \mathrm{~m}_{4}$ are lag length corresponding to each variable, calculated by ARDL model following AIC, SC, HQ criteria and adjusted R-squared. And,

$$
\lambda_{1}^{+}=-\left(\beta_{2}^{+} / \beta_{1}\right), \lambda_{1}^{-}=-\left(\beta_{2}^{-} / \beta_{1}\right)
$$

In order to test the asymmetry effects of inflation on growth, the estimate of the nonlinear model by Ordinary Least Square technique is then used to judge four types of asymmetry. First, short-run asymmetry is established if $\alpha_{\hat{2}}^{\text {岁 }} \neq \alpha_{2 i}^{-}$for each individual $i$. Second, the short-run impact asymmetry is established

$$
\text { if } \sum_{i=0}^{m 2} \frac{4}{\alpha_{2 i}} \neq \sum_{i=0}^{m 3} \alpha_{2 i}^{-}
$$

Third, long-run asymmetry is established if $\overrightarrow{\beta_{2}} \neq \beta_{2}^{-}$ or $\lambda_{1}^{-1} \neq \lambda_{1}^{-}$. Finally, adjustment asymmetry is captured by the pattern of dynamic multipliers. The asymmetries are tested using the Wald test. In addition to the research results are reliable, we will test the CUSUM (Cumulative Sum of Recursive Residuals) and CUSUMSQ (Cumulative Sum of Square Recursive Residuals) to check the stability of the long-run and short-run impacts.

\section{Empirical Results and Discussion}

\subsection{Descriptive Statistics}

Since 1986, Vietnam has experienced high rates of economic growth, changing the nation from a backward and underdeveloped country in the 1980 s to a developing economy increasingly converging to fast-growing regional economics. In 2017, the GDP per capita of Vietnam was 1,834.65 USD (at constant 2010 prices). The monetary authority has implemented many policies to curb hyperinflation in the decade 1980s. The rate of inflation tends to decline and stabilize below $10 \%$ in the last recent years. The descriptive statistics of variables in the models are shown in Table 2.

Table 2: Descriptive statistics

\begin{tabular}{|c|c|c|c|c|}
\hline Variables & Mean & Max & Min & Std.Error \\
\hline LnGDP & 6.809 & 7.515 & 6.051 & 0.450 \\
\hline INF & 11.67 & 67.6 & -1.71 & 16.75 \\
\hline MS & 70.67 & 155.28 & 18.91 & 44.67 \\
\hline
\end{tabular}

\subsection{Empirical Results}

\subsubsection{Stationarity Test}

It is well documented in the existing time series econometric literature that regression results may be spurious if the estimated variables are non-stationary and/or not cointegrated. In light of this, testing for a unit root of each series is necessary. To investigate the order of cointegration, we employed the Dickey and Fuller (1981) (ADF) test, and the Perron and Phillips (1988) (PP) test. Results of the ADF test and PP test are shown in Table 3.

Table 3: Stationarity test

\begin{tabular}{|c|c|c|}
\hline Variables & ADF test & PP test \\
\hline LnGDP & -1.271 & -1.522 \\
\hline$\Delta \mathrm{LnGDP}$ & $-2.716^{*}$ & $-3.085^{* *}$ \\
\hline $\mathrm{INF}$ & $-4.271^{* * *}$ & $-9.001 * * *$ \\
\hline$\Delta \mathrm{INF}$ & $-7.654^{* * *}$ & $-4.836^{* * *}$ \\
\hline $\mathrm{MS}$ & 1.278 & 1.487 \\
\hline$\Delta \mathrm{MS}$ & $-4.975^{* * *}$ & $-4.974 * * *$ \\
\hline$* * *, * *$ and $*$ respectively denote significance levels of $1 \% ; 5 \%$ and $10 \%$.
\end{tabular}

Results in Table 3 shown the INF variable is stationary at $\mathrm{I}(0)$. LnGDP and MS variables are stationary at I(1). No variable is stationary at $I(2)$. Hence, the conditions to apply the NARDL of Shin et al. (2013) are satisfied.

\subsubsection{Determination of Optimal Lag Length}

In the NARDL model, the determination of optimal lag length is important. Thereby, the number of previous periods in which economic growth influences the current one can be identified. With the initial lag length inputted of 4, the NARDL model automatically calculates optimal lag lengths. According to $\mathrm{AIC}, \mathrm{SC}$ and $\mathrm{HC}$ criteria, the maximum lag length is 2 , in the case of Vietnam. Then, in Eq. 3 , the value of $m_{1}, m_{2}, m_{3}, m_{4}$ is lower or equal 2.

\subsubsection{Bounds Test}

According to Engle and Granger (1987) on series data, there may be long-run cointegrations between variables. The long-run cointegration can be determined by Fstatistics suggested by Pesaran et al. (2001).

Table 4: Results of the cointegration test

\begin{tabular}{|c|c|c|c|c|}
\hline \multicolumn{2}{|c|}{ F-Bound test for Eq.3 } & \multicolumn{3}{c|}{ Null Hypothesis: No levels relationship } \\
\hline Test Statistic & Value & Signif & $\mathrm{I}(0)$ & $\mathrm{I}(1)$ \\
\hline F-statistic & 4.415 & $10 \%$ & 2.37 & 3.2 \\
\hline $\mathrm{k}$ & 3 & $5 \%$ & 2.79 & 3.67 \\
\hline & & $2.5 \%$ & 3.15 & 4.08 \\
\hline & & $1 \%$ & 3.65 & 4.66 \\
\hline
\end{tabular}


As the linear ARDL approach, Shin et al. (2013) proposed the Bounds test. Table 4 shows that F-statistic = $4.415>$ Upper bound $\mathrm{I}(1)=3.67$ at the $5 \%$ significance level (this implied the null hypothesis is rejected). Thus, the results of the Bounds test reveal that there exist long-term cointegrations between LnGDP, INF, MS variables. Then Eq.3 should be estimated with the Error Correction Model.

\subsubsection{Error Correction Model}

There are long-run cointegrations between variables in our model, thus Eq. 3 is estimated with the error correction model to determine impact coefficients in the short term. Results of the short-term impacts of inflation and money supply on economic growth are shown in Table 5 .

Estimated results show that $\operatorname{ECM}(-1)=-0.1633$ at the $1 \%$ significance level. This implies that economic growth is able to adjust to long-run equilibrium after each short-run "shock" created by inflation and money supply. But, the results in Table 5 also provides evidence that the asymmetric effects of inflation on growth are not clear, in the short run.

Table 5: Results of Error Correction Model

\begin{tabular}{|c|c|c|c|c|}
\hline Variable & Coefficient & Std. Error & t-Statistic & Prob \\
\hline ECM(-1) & -0.1633 & 0.0436 & -3.74 & 0.003 \\
\hline$\Delta$ LnGDP(-1) & 0.4837 & 0.2018 & 2.40 & 0.035 \\
\hline$\Delta$ INF_POS & -0.0011 & 0.0007 & -1.55 & 0.150 \\
\hline$\Delta$ INF_POS(-1) & -0.0013 & 0.0006 & -2.10 & 0.059 \\
\hline$\Delta$ INF_NEG & 0.0003 & 0.0006 & 0.53 & 0.606 \\
\hline$\Delta$ INF_NEG(-1) & 0.0006 & 0.0002 & 3.39 & 0.006 \\
\hline$\Delta$ MS & 0.0004 & 0.0002 & 2.70 & 0.013 \\
\hline Intercept & 1.0602 & 0.2593 & 4.09 & 0.002 \\
\hline
\end{tabular}

\subsubsection{Diagnostic and Stability Test}

We will conduct additional diagnostic tests including the heteroskedasticity test, autocorrelation test, distribution test, stability test through examining the cumulative sum of recursive residuals (CUSUM) and cumulative sum of square recursive residuals (CUSUMSQ).
Table 6: Diagnostic test

\begin{tabular}{|c|c|}
\hline Type of test & Obs * $\mathbf{R} \_$square \\
\hline Heteroskedasticity test & $2.888($ Prob $=0.0892)$ \\
\hline Serial correlation LM test & $14.08($ Prob $=0.2284)$ \\
\hline Ramsey RESET test & $0.767($ Prob $=0.5437)$ \\
\hline Jarque-Bera test on normality & $2.019($ Prob $=0.3643)$ \\
\hline
\end{tabular}

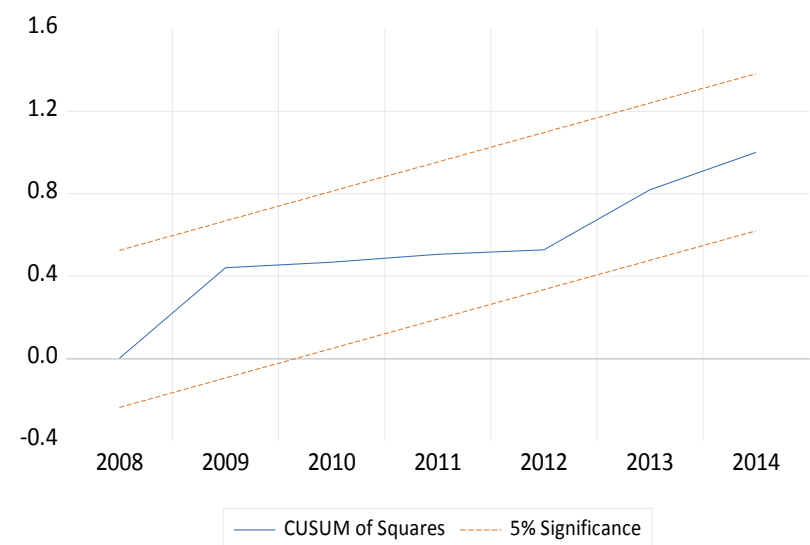

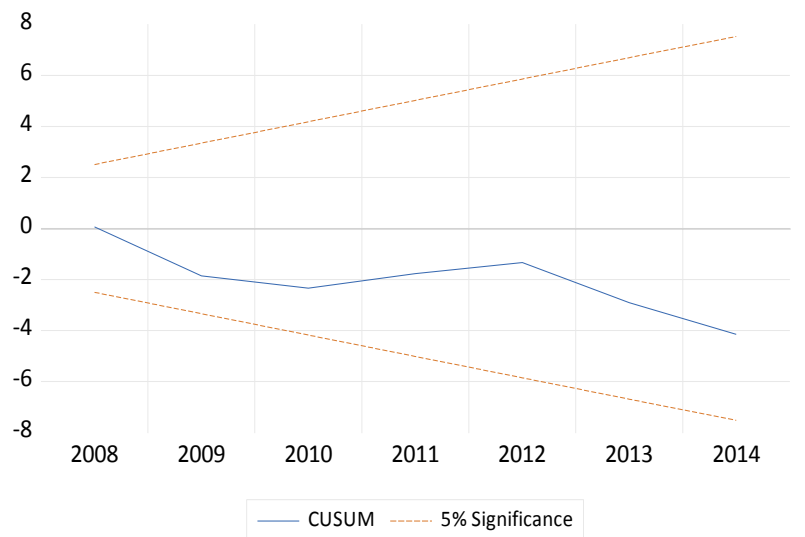

Figure 1: Results of the CUSUM and CUSUMSQ test

According to results in Table 6, heteroskedasticity and autocorrelation were not found in the model, and residuals were normally distributed. Figure 1 shows that both CUSUM and CUSUMSQ lines (solid lines) of Eq.3 are within the critical bounds at a significant level of $5 \%$ (dashed lines). Thus it can be concluded that Eq.3 is stable, and the estimated results are reliable for further analysis and prediction. 


\subsubsection{Estimated Results of Long-run Impacts}

To identify the asymmetry effects of inflation on the growth of Vietnam in the 1990-2017 period, coefficients are estimated in the long run. The existence of the long-run symmetry is tested by the Wald test.

With the null hypothesis: $H_{0 L \mathrm{R}}: \lambda_{1}^{+}=\lambda_{1}^{-}$

against the alternative hypothesis: $H_{1 L \mathrm{R}}: \lambda_{1}^{+} \neq \lambda_{1}^{-}$.

For checking short-run symmetry,

$$
\begin{aligned}
& \text { null hypothesis: } H_{0 S \mathrm{R}}: \sum_{i=0}^{m 2} \alpha_{2 i}^{+}=\sum_{i=0}^{m 3} \alpha_{2 i}^{-} \\
& \text {against the } \begin{array}{l}
\text { alternative hypothesis: } \\
H_{1 S \mathrm{R}}: \sum_{i=0}^{m 2} \alpha_{2 i}^{+} \neq \sum_{i=0}^{m 3} \alpha_{2 i}^{-}
\end{array}
\end{aligned}
$$

If the null hypothesis is rejected, it is evidence to concludes that there is an asymmetry effect in Eq.3. According to Banerjee, Dolado, and Mestre (1998), the cumulative dynamic multiplier effects of INF_POS and INF_NEG on economic growth can be evaluated as follows:

$$
m_{h}^{+}=\sum_{i=0}^{h} \frac{\partial I N F_{t+i}}{\partial I N F_{-} P O S} ; m_{h}^{-}=\sum_{i=0}^{h} \frac{\partial I N F_{t+i}}{\partial I N F_{-} N E G}
$$

Note that as $h \rightarrow \infty$ then $m_{h}^{+} \rightarrow \lambda_{1}^{+}, m_{h}^{-} \rightarrow \lambda_{1}^{-}$, where $\lambda_{1}^{+}$and $\lambda_{1}^{-}$are the asymmetric long-run coefficients. Estimated results in Table 7 show that $\lambda_{1}^{+}=-0.010$ (INF_POS) at the significance level of 5\% ; $\lambda_{1}^{-}=0.002$ (INF_NEG) and not yet significant. Results of the Wald test in Table 8 show that $\mathrm{W}_{\mathrm{LR}}=9.593$ (Prob $=$ 0.01 ), this implied $H_{O L R}$ is rejected, and $\mathrm{W}_{\mathrm{SR}}=5.803$ (Prob $=0.035$ ), this implied $H_{O S R}$ is rejected. These results provide

\begin{tabular}{|c|c|c|c|}
\hline Variables & Coefficient & t_statistic & Prob \\
\hline INF_POS & -0.010 & -7.060 & 0.022 \\
\hline INF_NEG & 0.002 & 0.624 & 0.446 \\
\hline MS & 0.016 & 30.67 & 0.000 \\
\hline \multicolumn{2}{|c|}{ Long-run asymmetry test } & \multicolumn{2}{|c|}{ Short-run asymmetry test } \\
\hline & F statistic & & F statistic \\
\hline INF & $\begin{aligned} \mathrm{W}_{\mathrm{LR}} & =9.593 \\
(\mathrm{Prob} & =0.010)\end{aligned}$ & & $\begin{aligned} \mathrm{W}_{\mathrm{SR}} & =5.803 \\
(\mathrm{Prob} & =0.035)\end{aligned}$ \\
\hline
\end{tabular}
evidence to conclude the effect of inflation on economic growth is asymmetry. Accordingly, there is a negative impact on growth from inflation in the long run.

Table 7: Estimated results of long-run impacts

\section{Conclusion and Policy Implications}

Using annual data in the period 1990-2017, by applying Nonlinear Autoregressive Distributed Lag approach purposed by Shin et al. (2013) this study affirms two following main points:

(i) There is a strong statistics evidence to conclude that the impact of inflation on economic growth is asymmetry in the long run. There is a negative impact of inflation on economic growth in the case of Vietnam.

(ii) Money supply has a positive impact on growth in both the short-run and long run. Based on empirical results, the authors propose some policy implications, as follows:

Firstly: The monetary authorities need to rotate the expanded monetary policy and the shrinking monetary policy. Because increasing the money supply will help promote growth rate, but the extreme money supply policy maybe harms growth.

Secondly: Inflation has negative impacts on economic growth in the case of Vietnam, and high inflation will destruct economic activities. In order to achieve high and sustainable rates of growth, the Government should maintain low and stable rates of inflation.

\section{References}

Ayres, K., Belasen, A. R., \& Kutan, A. M. (2014). Does inflation targeting lower inflation and spur growth? Journal of Policy Modeling, 36(2), 373-388.

Banerjee, A., Dolado, J. J., \& Mestre, R. (1998). Errorcorrection mechanism tests for cointegration in a singleequation framework. Journal of Time Series Analysis, 19(3), 267-283.

Bhar, R., \& Mallik, G. (2010). Inflation, inflation uncertainty and output growth in the USA. Physica A: Statistical Mechanics and Its Applications, 389(23), 5503-5510.

Bruno, M., \& Easterly, W. (1998). Inflation crises and longrun growth. Journal of Monetary Economics, 4l(1), $3-$ 26.

Burdekin, R. C. K., Denzau, A. T., Keil, M. W., Sitthiyot, T., \& Willett, T. D. (2004). When does inflation hurt economic growth? Different nonlinearities for different economies. Journal of Macroeconomics, 26(3), 519532.

Dickey, D. A., \& Fuller, W. A. (1981). Likelihood Ratio Statistics for Autoregressive Time Series with a Unit Root. Econometrica, 49(4), 1057-1072.

Dornbusch, R., \& Frenkel, J. A. (1973). Inflation and Growth: Alternative Approaches. Journal of Money, Credit and Banking, 5(1), 141-156. 
Engle, R. F., \& Granger, C. W. J. (1987). Co-Integration and Error Correction: Representation, Estimation, and Testing. Econometrica, 55(2), 251-276.

Fischer, S. (1993). The role of macroeconomic factors in growth. Journal of Monetary Economics, 32(3), 485512.

Fountas, S. (2010). Inflation, inflation uncertainty and growth: Are they related? Economic Modelling, 27(5), 896-899.

Ghosh, A., \& Phillips, S. (1998). Warning: Inflation May Be Harmful to Your Growth. IMF Staff Papers, 45(4), 672-710.

Gillman, M., \& Harris, M. N. (2010). The effect of inflation on growth. Economics of Transition, 18(4), 697-714.

Hayat, Z., Balli, F., \& Rehman, M. (2018). Does inflation bias stabilize real growth? Evidence from Pakistan. Journal of Policy Modeling, 40(6), 1083-1103.

Hwang, Y. (2007). Causality between inflation and real growth. Economics Letters, 94(1), 146-153.

Hung, F.-S. (2017). Explaining the nonlinearity of inflation and economic growth: The role of tax evasion. International Review of Economics and Finance, 52, 436-445.

Ibarra, R., \& Trupkin, D. R. (2016). Reexamining the relationship between inflation and growth: Do institutions matter in developing countries? Economic Modelling, 52, 332-351.

Ilyas, M., Sabir, H. M., Shehzadi, A., \& Shoukat, N. (2014). Inter-relationship among Economic Growth, Savings and Inflation in Pakistan. Journal of Finance and Economics, 2(4), 125-130.

Khan, M., \& Senhadji, A. (2000). Threshold effects in the relationship between inflation and growth. IMF Staff Paper, 48, 1-21.

Kiat, J. (2008). The effect of the exchange rate and inflation on foreign direct investment and its relationship with economic growth in South Africa. Economics and Applied Informatics, 17(1), 5-16.

Lam, H. T. (2015). Threshold effects in the relationship between inflation and economic growth in Vietnam. Vietnam Journal of Economics and Development, 217(7), 29-37.
Law, S. H., \& Singh, N. (2014). Does too much finance harm economic growth? Journal of Banking and Finance, 41(1), 36-44.

López-Villavicencio, A., \& Mignon, V. (2011). On the impact of inflation on output growth: Does the level of inflation matter? Journal of Macroeconomics, 33(3), 455-464.

Munir, Q., Mansur, K., \& Furuoka, F. (2009). Inflation and Economic Growth in Malaysia - A Threshold Regression Approach. ASEAN Economic Bulletin, 26(2), 180-193.

Perron, P., \& Phillips, P. C. B. (1988). Testing for a Unit Root in Time Series Regression. Biometrika, 75(2), 335-346.

Pesaran, M. H., Shin, Y., \& Smith, R. J. (2001). Bounds testing approaches to the analysis of level relationships. Journal of Applied Econometrics, 16(3), 289-326.

Rousseau, P. L., \& Yilmazkuday, H. (2009). Inflation, financial development, and growth: A trilateral analysis. Economic Systems, 33(4), 310-324.

Shin, Y., Byungchul, Y., \& Greenwood-nimmo, M. (2013). Modeling Asymmetric Cointegration and Dynamic Multipliers in an ARDL Framework. SSRN Electronic Journal, 44(0), 1-35.

Sidrauski, M. (1967). Inflation and Economic Growth. Journal of Political Economy, 75, 796-810.

Tobin, J. (1965). Money and economic growth. Econometrica, 33(4), 671-684.

Tuan, T. M. (2013). The relationship between inflation and economic growth: Evidence from Vietnam. Vietnam Journal of Development and Economics, 278(12), 2-12.

Vaona, A., \& Schiavo, S. (2007). Nonparametric and semiparametric evidence on the long-run effects of inflation on growth. Economics Letters, 94(3), 452-458.

Wallich, H. C. (1969). Money and Growth: A Country Cross-Section Analysis. Journal of Money, Credit and Banking, 1(2), 281-302.

Wulandari, D., Utomo, S. H., Narmaditya, B. S., \& Kamaludin, M. (2019). Nexus between Inflation and Unemployment: Evidence from Indonesia. Journal of Asian Finance, Economics and Business, 6(2), 269-275. 